\title{
Use of dried blood spots for the detection and confirmation of HTLV-I specific antibodies for epidemiological purposes
}

\author{
S P Parker, M B Taylor, A E Ades, W D Cubitt, C Peckham
}

\begin{abstract}
Aims-To modify and evaluate a gelatin particle agglutination test that could provide a sensitive, specific and inexpensive method for the detection of HTLV-I antibody in dried blood spot samples (DBS) collected on filter paper.
\end{abstract}

Methods-A set of 26 reference samples confirmed as HTLV-I antibody positive were assembled from patients with tropical spastic paraparesis or adult $T$ cell leukaemia and blood donors. Serum samples and simulated antibody positive dried blood spot eluates were tested using the Serodia assay together with two confirmatory tests: HTLV BLOT 2.3, a western blot, and Select-HTLV, an enzyme immunoassay (EIA). Both confirmatory tests use synthetic peptides to differentiate between antibodies to HTLV-I and -II. The modified Serodia assay was then used to test anonymously 10135 DBS collected from neonates from London. Samples reactive in the modified Serodia test producing a positive result were titrated to an end point and confirmed as before.

Results-All 26 eluates made from simulated DBS derived from positive reference samples were identified as positive by the modified Serodia HTLV-I test and were confirmed as anti-HTLV-I positive by EIA. Two eluates derived from relatively low titre reference samples gave indeterminate results on western blotting. Screening of the 10135 neonatal DBS resulted in six repeat reactives, five of which were confirmed. The remaining reactive sample gave an indeterminate result on western blotting and there was insufficient eluate for testing by EIA. The overall seroprevalence of HTLV-I in this population was $0.05 \%$ (five of 10135 ).

Conclusion-The modified Serodia HTLVI assay provides a sensitive, specific and inexpensive (10 pence/test) method for screening large numbers of DBS. The format of the assay makes it ideally suited for simultaneous screening of antibodies to HIV-1, HIV-2 and HTLV-I using semiautomated equipment.

( $($ Clin Pathol 1995;48:904-907)

Keywords: HTLV-I, dried blood spots, antibodies.

Human $\mathrm{T}$ cell lymphotropic virus type I (HTLV-I) has been recognised as the causal agent of several diseases, adult $\mathrm{T}$ cell leukaemia (ATL), ${ }^{1}$ tropical spastic paraparesis (TSP), ${ }^{2}$ also known as HTLV-I associated myelopathy
(HAM) in Japan, ${ }^{3}$ and, more recently, HTLV-I uveitis. ${ }^{4}$ Transmission may occur through the transfer of infected lymphocytes ${ }^{5}$ by sexual transmission, ${ }^{6}$ during transplantation (blood or organ), intravenous drug abuse, breast feeding, ${ }^{7}$ and possibly saliva. ${ }^{8}$

HTLV-I is endemic in Japan (where over 700 cases of ATL are diagnosed every year), ${ }^{9}$ the Caribbean, ${ }^{10}$ South America, ${ }^{11}$ central and southern Africa, ${ }^{12-14}$ and occurs in Australian aborigines, ${ }^{15}$ and in intravenous drug users in the USA. ${ }^{16}$

Many assays have been developed for the detection of HTLV-I antibody and antigen, including antigen capture, immunofluorescence, the polymerase chain reaction (PCR), and in situ hybridisation. ${ }^{17} 18$ The Serodia test, a gelatin particle agglutination assay, is a highly sensitive test introduced in 1987 for the detection of antibodies to HTLV-I. ${ }^{19}{ }^{20}$ However, following concerns about the test's specificity in comparison with other assays such as the radioimmunoprecipitation assay (RIPA) and western blot, ${ }^{20-22}$ particularly when it was used to test serum samples from Africans, ${ }^{23}$ the test was modified by increasing the relative proportion of env to gag proteins. ${ }^{24}$ Subsequent evaluation of the assay in comparison with other commercial tests showed it to have superior specificity, $97 \cdot 6 \%$, and sensitivity, $100 \% .{ }^{25}$ In spite of improvements in the screening assay confirmatory testing remains essential as cross reactivity with HTLV-II has been reported. ${ }^{26}$ The most reliable technique for the differentiation of HTLV-I and HTLV-II is PCR and the use of type specific recombinant proteins in enzyme immunoassays (EIAs) and western blots have improved the differentiation of antibodies to the two viruses. ${ }^{2728}$

The improved Serodia test has been used extensively for epidemiological surveys to estimate the seroprevalence of HTLV-I in blood donors in the United Kingdom, ${ }^{26}$ France, ${ }^{29}$ Japan, ${ }^{9}$ and Australia. ${ }^{30}$ In this paper we describe the use of a modified version of the Serodia test to screen for the presence of antibody to HTLV-I in dried blood spot samples from anonymous neonatal Guthrie cards followed by confirmatory testing.

\section{Methods}

REFERENCE SAMPLES

Twenty six samples were obtained from patients with confirmed HTLV-I infection, from three sources. Seven plasma samples originating from the Japanese Red Cross (ADP 507, MRC AIDS Reagent Project) were provided by the National Institute of Biological Standards, UK. Serum samples from four

Correspondence to: Mr S P Parker. 
patients with TSP associated symptoms diagnosed as HTLV-I positive at St Bartholomew's Hospital, London, were included together with 15 samples from African patients with symptoms of TSP or ATL referred to the University of Pretoria, Republic of South Africa. All samples had been confirmed as anti-HTLV-I positive by other laboratories.

\section{SIMULATED HTLV-I POSITIVE DRIED BLOOD SPOT SAMPLES}

A 1 in 2 dilution of each anti-HTLV-I positive sample, or serial dilutions, were made in antiHTLV-I negative human " $O$ " cells and a $60 \mu \mathrm{l}$ aliquot spotted out onto absorbent filter paper (Guthrie card). Cards were allowed to dry at room temperature overnight before storage at $4^{\circ} \mathrm{C}$ in gas permeable bags.

\section{SOURCE OF NEONATAL DRIED BLOOD SPOT SAMPLES}

Dried blood spot samples punched from 10135 Guthrie cards that had been routinely collected for universal newborn metabolic screening were obtained from health districts in inner London with a relatively high proportion of Caribbean and African ethnic populations. All samples were rendered anonymous prior to receipt in the laboratory.

\section{ASSAY FOR THE DETECTION OF HTLV-I}

ANTIBODY IN SERUM SAMPLES

Serodia HTLV-I gelatin particle agglutination tests (Fujirebio Inc, Tokyo, Japan) were obtained from Mast Diagnostics, Bootle, Merseyside, UK.

Serum and plasma samples were tested according to the manufacturer's instructions. Briefly, samples were titrated in a series of doubling dilutions from 1 in 16 across a $U$ well microtitre plate; $25 \mu$ l of sensitised particle suspension was added to each well. The contents of each well were thoroughly mixed using a plate shaker, and left to incubate at room temperature for two hours on a level, vibration free surface.

Positive results were indicated by the formation of an agglutination pattern and negative results were indicated by a smooth compact button of particles.

\section{DRIED BLOOD SPOT SAMPLE ASSAY}

A dried blood spot sample, $5.5 \mathrm{~mm}$ in diameter, was punched out of each Guthrie card and eluted, as described previously, ${ }^{31}$ into flat bottomed microtitre plates containing $100 \mu \mathrm{l}$ buffer (phosphate buffered saline $(\mathrm{pH} \mathrm{7 \cdot 2)}$ containing $0.05 \%$ Tween 80 and $0.005 \%$ sodium azide) overnight at $4^{\circ} \mathrm{C}$. A 1 in 6 dilution of each eluate was made in TPHA buffer (catalog number 9224, Mast Diagnostics), in a corresponding $\mathrm{V}$ well plate using a 96 pin automatic replicator calibrated to transfer $5 \mu \mathrm{l}$ aliquots, (Wellrepp, Denley Instruments, Billinghurst, Sussex, UK). HTLV-I gelatin particles were reconstituted according to the manufacturer's instructions and then diluted 10-fold in TPHA buffer immediately before use. A $25 \mu \mathrm{l}$ aliquot of diluted particles was added to each well using an automated programmable dispenser (Wellfill, Denley Instruments). The plates were incubated for 15 minutes at room temperature on a flat, vibration free surface and were then centrifuged for three minutes at $200 \times g$, sloped on a lightbox at an angle of $70^{\circ}$, and the results read after 10 minutes. A positive result could be distinguished by a tight discrete agglutination pattern whereas negative samples formed a teardrop.

All eluates found to be reactive in the initial screen were titrated in a series of doubling dilutions from 1 in 5 to 1 in 10240 or 1 in 4 to 1 in 16384 in TPHA buffer, and reacted against both antigen coated particles and unsensitised control particles and the endpoint recorded.

\section{CONFIRMATORY TESTING}

A repeat reactive screening result was confirmed using western blot analysis (HTLVBLOT 2.3, Diagnostic Biotechnology, Singapore) and an EIA (Select-HTLV, IFCI Clonesystems, Biostat Diagnostics, Cheshire, UK).

The HTLV BLOT $2 \cdot 3$ contains viral lysate, recombinant rgp21 (env), and incorporates MTA-1 and K55 recombinant peptides corresponding to sequences specific to gp $46^{\text {env }}$ of HTLV-I and -II, respectively. A 1 in 100 dilution of serum $(20 \mu \mathrm{l}$ in $2.0 \mathrm{ml})$ was tested according to the manufacturer's instructions. The presence of bands to the envelope proteins rgp21 and rgp46-I and core proteins p1 $9^{\text {gag }}$ or p $24^{\mathrm{gag}}$ was regarded as the minimum criterion indicative of antibody to HTLV-I.

The Select-HTLV kit differentiates between antibodies to HTLV-I and -II using synthetic peptides representing type specific epitopes derived from $\mathrm{p} 19^{\mathrm{gag}}$ and $\mathrm{gp} 52^{\text {env }}$, respectively. Serum samples were tested at a 1 in $50(5 \mu \mathrm{l}$ in $250 \mu \mathrm{l}$ ) dilution and results interpreted according to the manufacturer's instructions. Optical densities (OD) of samples greater than the cut off value (mean of three negative controls ((supplied) $+0 \cdot 15)$ were considered positive. When the cut off value was exceeded on both the HTLV-I and -II plates, a binding ratio (OD HTLV-II/OD HTLV-I) was calculated and a ratio of $\leq 0.5$ was considered indicative of reactivity to HTLV-I.

Minor modifications were required when applying the confirmatory tests to dried blood spot samples in that a volume of $40 \mu$ l eluate was used in the western blot assay and $20 \mu \mathrm{l}$ in the EIA. Simulated dried blood spot samples derived from serially diluted reference antibody positive and antibody negative eluate controls were used to provide an accurate cut off point in the EIA.

\section{Results}

\section{REFERENCE PANEL}

The results of tests on HTLV-I positive reference serum and plasma samples and eluates from simulated dried blood spot samples are shown in table 1. Use of the standard Serodia HTLV-I test and confirmatory assays on the reference samples gave the expected results. 
Table 1 Results of screening and confirmatory tests on 26 reference samples and simulated dried blood spot samples (DBS)

\begin{tabular}{|c|c|c|c|c|c|c|c|}
\hline \multirow[b]{2}{*}{ Sample } & \multirow[b]{2}{*}{ Diagnosis } & \multicolumn{3}{|c|}{ Reference sample } & \multicolumn{3}{|c|}{ Simulated DBS eluate } \\
\hline & & Serodia titre & $\begin{array}{l}H T L V \\
B L O T 2 \cdot 3\end{array}$ & Select-HTLV* & Serodia titre & $\begin{array}{l}H T L V \\
B L O T 2 \cdot 3\end{array}$ & Select-HTLV* \\
\hline 1 & TSP & 80000 & + & $>3.0$ & 16384 & + & $2 \cdot 84$ \\
\hline 2 & TSP & 80000 & + & $2 \cdot 88$ & 8192 & + & $2 \cdot 84$ \\
\hline 3 & TSP & 80000 & + & $2 \cdot 84$ & 8192 & + & 2.91 \\
\hline 4 & TSP & 64000 & + & $2 \cdot 79$ & 8192 & + & $2 \cdot 84$ \\
\hline 5 & TSP & 64000 & + & $2 \cdot 84$ & 4096 & + & $2 \cdot 77$ \\
\hline 6 & TSP & 64000 & + & $>3.0$ & 2048 & + & $2 \cdot 84$ \\
\hline 7 & TSP & 64000 & + & $>3.0$ & 1024 & + & $2 \cdot 24$ \\
\hline 8 & TSP & 32000 & + & 2.59 & 4096 & + & 1.38 \\
\hline 9 & TSP & 32000 & + & $2 \cdot 69$ & 2048 & + & $2 \cdot 44$ \\
\hline 10 & TSP & 32000 & + & $2 \cdot 89$ & 2048 & + & $2 \cdot 15$ \\
\hline 11 & TSP & 32000 & + & $2 \cdot 74$ & 1024 & + & 2.06 \\
\hline 12 & TSP & 32000 & + & $2 \cdot 77$ & 512 & + & 1.78 \\
\hline 13 & TSP & 16000 & + & $>3.0$ & 512 & + & 2.70 \\
\hline 14 & ATL & 16000 & + & $>3.0$ & 160 & + & 1.72 \\
\hline 15 & TSP & 8000 & + & $2 \cdot 52$ & 256 & + & 0.39 \\
\hline 16 & TSP & 8000 & + & $>3.0$ & 32 & + & 0.68 \\
\hline 17 & TSP & 2000 & + & $2 \cdot 23$ & 128 & + & 0.32 \\
\hline 18 & TSP & 2000 & + & $2 \cdot 80$ & 64 & + & 0.93 \\
\hline 19 & ATL & 2000 & + & $2 \cdot 88$ & 80 & + & 0.83 \\
\hline 20 & ATL & 1000 & + & 1.90 & 64 & $\mathrm{p} 24, \operatorname{rgp} 41$ & $0 \cdot 17$ \\
\hline 21 & ATL & 1000 & + & $2 \cdot 58$ & 80 & + & 0.74 \\
\hline 22 & ATL & 1000 & + & $2 \cdot 82$ & 40 & + & 0.47 \\
\hline 23 & ATL & 500 & + & $2 \cdot 67$ & 20 & + & 0.65 \\
\hline 24 & ATL & 400 & + & $2 \cdot 44$ & 80 & & 0.47 \\
\hline 25 & ATL & 200 & + & 1.65 & 16 & $\mathrm{p} 24, \mathrm{rgp} 41$ & 0.19 \\
\hline 26 & ATL & 100 & + & 1.50 & 10 & + & 0.17 \\
\hline
\end{tabular}

$\mathrm{TSP}=$ tropical spastic paraparesis; $\mathrm{ATL}=$ adult $\mathrm{T}$ cell leukaemia * OD of HTLV-I plate.

All tests on eluates from simulated dried blood spot samples gave positive results using the modified Serodia agglutination test (table 1). When eluates were tested against unsensitised particles provided in the Serodia test there was no evidence of non-specific agglutination.

Confirmatory testing by western blotting produced two indeterminate results (samples 20 and 25), suggesting that two of 26 eluates were on or just below the limit of sensitivity of

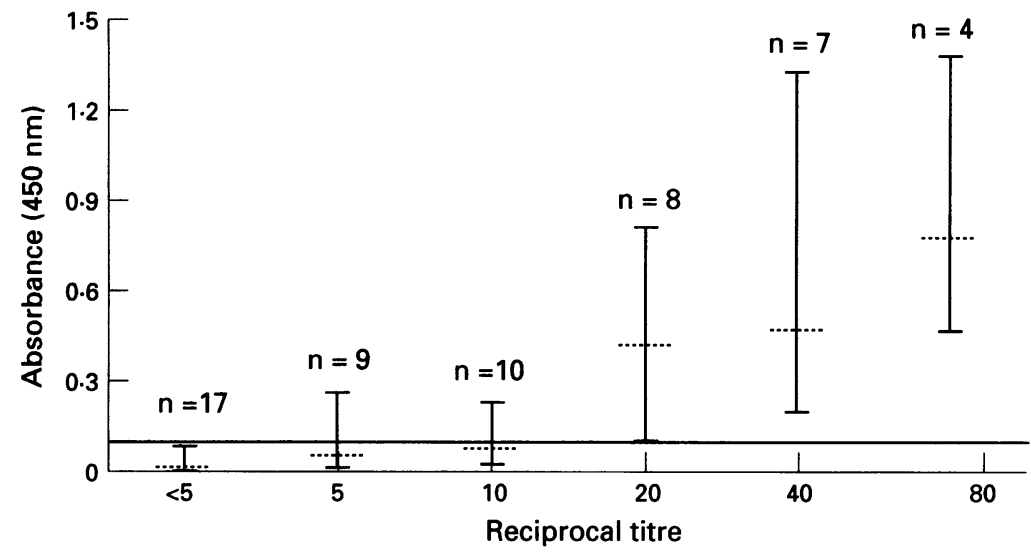

Comparison of the absorbance values obtained in the EIA and the titre observed in the modified Serodia test. $n=$ number of samples; .... median value; closed bars denote range.

Table 2 Results of screening and confirmatory testing of repeat reactive eluates derived from anonymous neonatal dried blood spot samples

\begin{tabular}{llllll}
\hline \multirow{2}{*}{$\begin{array}{l}\text { Sample } \\
\text { No. }\end{array}$} & $\begin{array}{l}\text { Serodia } \\
\text { eluate titre }\end{array}$ & $\begin{array}{l}\text { HTLV } \\
\text { BLOT 2-3 }\end{array}$ & \begin{tabular}{l} 
Select-HTLV \\
\cline { 4 - 6 } plate
\end{tabular} & $\begin{array}{l}\text { HTLV-II } \\
\text { plate }\end{array}$ & $\begin{array}{l}\text { Binding } \\
\text { ratio* }\end{array}$ \\
\hline 1 & $\leq 20$ & p19, rgp21 & INS & INS & INS \\
2 & 40 & HTLV-I+ & $1 \cdot 15$ & $0 \cdot 20$ & $0 \cdot 17$ \\
3 & 40 & HTLV-I+ & 0.35 & 0.07 & 0.20 \\
4 & 80 & HTLV-I+ & 1.38 & 0.18 & 0.13 \\
5 & 160 & HTLV-I+ & 0.37 & 0.07 & 0.19 \\
6 & 160 & HTLV-I+ & 0.58 & 0.06 & 0.10 \\
\hline
\end{tabular}

* Binding ratio OD $=$ HTLV-II/OD HTLV-I. A binding ratio of $\leq 0.5$ was indicative of reactivity to HTLV-I.

to HS = insufficient sample to test. the assay. All eluates derived from serum or plasma reference samples were positive in the EIA.

In order to set a cut off value for the EIA when confirming Serodia reactive eluates, simulated dried blood spot samples derived from serially diluted samples from the reference panel were tested in the modified Serodia HTLV-I and the EIA (figure). The figure shows that eluates with a Serodia titre greater than 1 in 10 can be reliably detected by the EIA using a cut off OD of $0 \cdot 1$. The mean and median ODs of Serodia negative $(<1$ in 5$)$ eluates were less than $0 \cdot 03$.

\section{NEONATAL PILOT STUDY RESULTS}

Twelve dried blood spot samples were initially reactive in the modified Serodia assay, of which six were negative when repeated. Five $(0.05 \%)$ of 10135 of the remaining six dried blood spot samples were confirmed as HTLV-I antibody positive by western blot and EIA (table 2). Sample 1, which had an end point titre of $\leq 20$, showed weak banding on western blotting to p1 $9^{\text {gag }}$ and rgp21 but was insufficient to test in the EIA.

\section{Discussion}

The modified Serodia HTLV-I assay was found to be sensitive when used to test simulated dried blood spot samples prepared from reference samples from patients in Japan, Africa and the UK. Comparison of the results of tests on serum and plasma samples and eluates showed that the modified Serodia test was more sensitive than the confirmatory assays when testing eluates from dried blood spot samples. Loss of sensitivity of the western blot with low titre eluates could be overcome by increasing the volumes of eluate. Although it has been suggested that the absence of a rgp21 positive band should be regarded as western blot negative in this assay, ${ }^{32}$ this would have resulted in two of the 26 eluates from the reference panel being recorded as negative. 
The Select-HTLV EIA confirmed all Serodia HTLV-I antibody positive eluates that had a titre greater than 1 in 10. Only one of 26 eluates derived from a reference serum sample had an eluate titre below this threshold, indicating that very few neonatal samples would be likely to have such low titres. However, it must be noted that patients with TSP, some of whose serum samples make up the reference panel, will in general have higher titres than those diagnosed with ATL or who are asymptomatic. ${ }^{33}$ Furthermore, studies have shown that premature infants have decreased levels of maternal IgG. ${ }^{34}$ In a London based neonatal screening survey approximately $1.5 \%$ of dried blood spot samples would be derived from neonates born seven to 12 weeks prematurely ${ }^{35}$ and would be expected to show a two- to fourfold loss of IgG.

Despite a potential problem in confirming very low positive eluates, the Select-HTLV would be the confirmatory test of choice for dried blood spot samples because of its adaptability when using limited volumes of eluate.

Five of six repeat reactive eluates were confirmed as positive from 10135 neonatal dried blood spot samples: a seroprevalence of $0.05 \%$ in pregnant women. This indicates that the modified Serodia assay has a very high specificity when testing samples obtained from neonates in the general population. The six initial reactives that failed to repeat were deemed technical failures perhaps due to dust contaminated wells as seen with similar frequency in other agglutination assays. The prevalence was lower than that reported $(0 \cdot 26 \%$ and $0 \cdot 21 \%$ ) in antenatal surveys from other London health districts, ${ }^{3637}$ but higher than the rates reported $(0.005 \%$ and $0.004 \%)$ in extensive surveys of blood donors in the UK. ${ }^{2126}$

The use of the modified Serodia HTLV-I test on dried blood spot samples collected from heal, finger or ear prick could provide a reliable, specific and sensitive test for economic large scale seroepidemiological studies. The stability of the samples on filter papers allows them to be collected without the need for refrigeration and tested centrally in laboratories with the appropriate equipment.

This work was supported by a Medical Research Council grant SPG9012930 and by a grant from the Child Health Research Appeal Trust. We would like to thank Dr H Kiyokawa and Dr $S$ Osmanov, from the MRC AIDS Reagent Project, Professor $\mathrm{H}$ Crewe-Brown and Frank Ward for providing us with reference material.

1 Hinuma $Y$, Nagata $K$, Hanoaka $M$, Nakai $M$, Matsumoto $\mathrm{T}$, Kinoshita $\mathrm{K}$, et al. Adult T-cell leukaemia antigen in an ATL cell line and detection of antibodies to the antigen in human sera. Proc Natl Acad Sci USA 1981;78:6476-80.

2 Gessain A, Vernant JC, Maurs L, Barin F, Gout O. Antibodies to human T-lymphotropic virus type $I$ in patients with tropical spastic paraparesis. Lancet 1985;ii:407-10.

3 Osame M, Usuku K, Izumo S, Ijichi A, Hiroyoko A, Igata $M$, et al. HTLV-I associated myelopathy, a new clinical entity. Lancet 1986;i:1031-2.

4 Mochizuki M, Watanabe T, Yamaguchi $K$, Takatsuki $K$, Yoshimura M, Shirao S, et al. HTLV-I uveitis: a distinct clinical entity caused by HTLV-I. Fpn $\mathcal{f}$ Cancer Res 1992; 83:236-9.

5 Okochi K, Sato H, Hinuma Y. A retrospective study on transmission of adult T-cell leukaemia virus by blood transfusion: serocoversion in recipients. Vox Sang 1984; 46:245-53.

6 Murphy EL, Figueroa JP, Gibbs WN, Braithwaite A, Holding-Cobham $M$, Waters $\mathrm{D}$, et al. Sexual transmission of human T-lymphotropic virus type I (HTLV-I). Ann Intern Med 1989;111:555-60.

7 Ichimaru M, Ikeda S, Kinoshita K, Hino S, Tsuji Y. Motherto-child transmission of HTLV-1. Cancer Detect Prev 1991; 15:177-81
8 Taniguchi S, Maekawa N, Yashiro N, Hamada T. Detection of human T-cell lymphotropic virus type-1 proviral DNA in the saliva of an adult T-cell leukaemia/lymphoma patient using the polymerase chain reaction. Br F Dermatol 1993; 129:637-41.

9 Yamaguchi K. Human T-lymphotropic virus type I in Japan Lancet 1994;343:213-6.

10 Catovsky D, Rose M, Goolden AWG, White JM, Bourikas G, Brownell AI, et al. Adult T-cell lymphoma-leukaemia in blacks from the West Indies. Lancet 1982;i:639-43.

11 Inostroza J, Diaz P, Saunier C. Prevalence of antibodies to HTLV-1 in South American Indians (Mapuches) from Chile. Scand $\mathcal{F}$ Infect Dis 1991;23:507-8.

12 Saxinger W, Blattner WA, Levine PH, Clark J, Biggar R, Moh M, et al. Human T-cell leukaemia virus (HTLV-I) in Africa. Science 1984;225:1473-6.

13 Jogessar VB, de Bruyn CC, Bhigjee AI, Naicker VL, Bill PL, Tait D. Adult T-cell leukaemia/lymphoma associated with HTLV-I in Natal. $S$ Afr Med f 1992;81:528-9.

14 Bhigjee AI, Kelbe C, Haribhai C, Windsor IM, Hoffman MH, Modi G, et al. Myelopathy associated with human T-cell lymphotropic virus type I (HTLV-I) in Natal, South Africa. Brain 1990;113:1307-20.

15 Bastian I, Hinuma Y, Doherty RR. HTLV-I among Northern Territory Aborigines. Med $\mathcal{F}$ Aust 1995;159:12-16.

16 Khabbaz RF, Onorato IM, Cannon RO, Hartley TM, Roberts B, Hosein B, et al. Seroprevalence of HTLV-1 and HTLV-2 among intravenous drug users and persons in clinics for sexually transmitted diseases. $N$ Engl $\mathcal{F}$ Med 1992;326:375-80.

17 White PMB. Comparison of assays for antibody to HTLV1. ₹ Clin Pathol 1988;41:700-2.

18 Beilke MA. Detection of HTLV-I in clinical specimens. $f$ Virol Methods 1992;40:133-44.

19 Catalan F, Ly TD, Milovanovic A. The evaluation of the Serodia-HIV and Serodia-ATLA FUJIREBIO-MILES kits. Ann Biol Clin Paris 1990;48:207-9.

20 Tosswill JHC, Parry JV, Weber JN. Application of screening and confirmatory assays for anti-HTLV-I/II in U.K. populations. $\mathcal{f}$ Med Virol 1992;36:167-71.

21 Salker R, Tosswill JHC, Barbara JAJ, Runganga J, Contreras M, Tedder RS, et al. HTLV-I/II antibodies in UK blood donors. Lancet 1991;336:317.

22 Weber JN, Banatvala N, Clayden S, McAdam KP, Palmer $\mathrm{S}$, Moulsdale $\mathrm{H}$, et al. HTLV-I infection in Papua New Guinea; evidence for serologic false positivity. $\mathcal{F}$ Infect Dis 1989;159:1025-8.

23 Verdier M, Denis F, Leonard G, Sangare A, Patillaud S, Prince-David $\mathrm{M}$, et al. Comparison of immunofluorescence, particle agglutination and enzyme immunoassays for the detection of human T-cell leukaemia virus type I antibody in African sera. F Clin Microbiol 1990;28: 1988-93.

24 Fujino R, Kawato K, Ikeda M, Miyakoshi H, Mizukoshi M, Imai J. Improvement of Gelatin Particle agglutination test for detection of anti-HTLV-I antibody. $\mathscr{F} n \mathcal{F}$ Cancer Res 1991;82:367-70.

25 Karopoulos A, Silvester C, Dax EM. A comparison of the performance of nine commercially available anti-HTLV-I screening assays. 7 Virol Methods 1993;45:83-91.

26 Brennan M, Runganga J, Barbara JAJ, Contreras M, Tedder RS, Garson JA, et al. Prevalence of antibodies to human $\mathrm{RS}$, Garson JA, et al. Prevalence of antibodies to human Tondon. BMF 1993;307:1235-9.

27 Lal RB, Heneine W, Rudolph DL, Present WB, Hofheinz $\mathrm{D}$, Hartley TM, et al. Synthetic peptide-based immunoassays for distinguishing between human T-cell lymphotropic virus type I and type II infections in seropositive individuals. F Clin Microbiol 1991;29:2253-8.

28 Lal RB, Brodine S, Kazura J, Mbidde-Katonga E, Yanagihara $R$, Roberts $C$. Sensitivity and specificity of a recombinant transmembrane glycoprotein (rgp21) spiked western immunoblot for serological confirmation of human T-cell lymphotropic virus type I and II infections. f Clin Microbiol 1992;30:296-9.

29 Courouce AM, Pillonel J, Lemaire JM, Maniez M, Brunet JB. Seroepidemiology of HTLV-I/II in universal screening of blood donations in France. AIDS 1993;7:841-7.

30 Bastian I, Dent J, McFarlane R, Karopoulos A, Way B. HTLV-I among Northern Territory blood donors. Med $\dot{f}$ HTLV-I among Norther

31 Ades AE, Parker S, Berry T, Holland FJ, Davison CF, Cubitt D, et al. Prevalence of maternal HIV-I infection in Thames Regions: results from anonymous unlinked neonatal testing. Lancet 1991;337:1562-5.

32 Gallo D, Diggs JL, Hanson CV. Evaluation of two commercial human T-cell lymphotropic virus western blot (Immunoblot) kits with problem specimens. $f$ Clin Microbiol 1994;32:2046-9.

33 Cruikshank JK, Rudge P, Dagleish AG, Newton M, McLean BN, Barnard RO, et al. Tropical spastic paraparesis and human T-cell leukaemia virus type $I$ in the United Kinghuman T-cell leukaemia virus type

34 Hobbs JR, Davis JA. Serum G-globulin levels and gestational age in premature babies. Lancet 1967;i:757-9.

$35 \mathrm{St} \mathrm{Mary's} \mathrm{maternity} \mathrm{information} \mathrm{system.} \mathrm{Northwest} \mathrm{Thames}$ region annual maternity figures 1992 . Northwest Thames region annual maternity

36 Banatvala JE, Chrysrie IL, Palmer SJ, Kenney A. Retrospective study of HIV, hepatitis B and HTLV-I infection at a London antenatal clinic. Lancet 1990;335: 859-60.

37 Tosswill JHC, Ades AE, Peckham C, Mortimer PP, Weber $J N$. Infection with human $T$ cell leukaemia/lymphoma virus type I in patients attending an antenatal clinic in London. BMF 1990;301:95-6. 